\title{
Vulvar Cancer pT3 TNM Finding v7
}

National Cancer Institute

\section{Source}

National Cancer Institute. Vulvar Cancer pT3 TNM Finding v7. NCI Thesaurus. Code C89426.

Vulvar cancer with tumor of any size with extension to any of the following:

upper/proximal 2/3 urethra, upper/proximal 2/3 vagina, bladder mucosa, rectal mucosa, or fixed to pelvic bone. (from AJCC 7th Ed.) 